\title{
Factors Influencing Farmers to Sustained Participation in Participatory Forestry: A Case Study in Central Sal Forest in Bangladesh
}

\section{A. Salam ${ }^{1}$, T. Noguchi ${ }^{2 *}$ and M. Koike2}

Department of Forest Science,

1. Professor, Department of Statistics, Jahangirnagar University, Savar, Dhaka, Bangladesh

Currently, Special Foreign Researcher under JSPS Fellowship, Faculty of Agriculture, Department of Forest Science, Shinshu University, Japan

2. Faculty of Agriculture, Shinshu University, Nagano-ken 399-4598, Japan. E-mail: salamju123@yahoo.com

Tel \& Fax: +81-0265-77-1536

* Corresponding author. 


\title{
Factors Influencing Farmers to Sustained Participation in Participatory Forestry: A Case Study in Central Sal Forest in Bangladesh
}

\begin{abstract}
Wide acceptance of sustainable development as a concept and goal of forest management has shifted forest management policy from traditional to people-oriented policy. Consequently, forest management has become more complex as there are now multiple objectives to attain. A gap exits between what is known and what is utilized one, which hinders the sustained participation of farmers. This gap arose mainly due to the interruption of the flow of information. In the case of participatory forestry, the flow of information requires a broader approach that goes beyond forests and trees and includes different stakeholders. Thus policy-makers, planners and project designers should incorporate relevant information in participatory forest management strategies within the context of dynamic interaction between stakeholders, trees and forests. They should understand the impact of factors such as policy, economics and conflicts on the sustained participation of farmers. This study aims at identifying factors that may influence farmers towards sustained participation in participatory forestry. The study is based on primary cross-sectional data. To meet the objective of the study, 581 participants were selected using stratified random sampling and data were collected through a structured questionnaire by interviewing the selected participants. In order to identify the dominant factors for sustained participation of farmers, logistic regression analysis was performed. The analysis noted the following results: (a) farmers' sustained participation is positively and significantly correlated with (i) satisfaction of participants with planted tree species
\end{abstract}


on their plots; (ii) confidence of participants on receiving aspired benefits; (iii) providing training to participants on different aspects of participatory forestry; and (iv) participant's contribution of money to Tree Farming Funds; and (b) farmers' sustained participation is negatively and significantly correlated with (i) disruption of local people's interests through implementation of participatory forestry program; and (ii) long delay in harvesting of trees after completion of contractual agreement period.

Key Words: Sustainable development, participatory forestry, sustained participation, assured financial benefits, statistical analysis.

\section{Introduction}

\subsection{Sustainable forest management}

Sustainable development has become widely accepted as a goal for management of forest and other natural resources. This goal has shifted forest management policy from one which emphasized sustainable harvesting of 'dominant products, primarily wood', to one which has focused mainly on managing the forests as a "complex, valuable natural resource system”.

Sustainable forest management is generally viewed as a logical extension of Brundtland's definition of sustainable development as it applies to forest management (Ferguson, 1996). Thus, the ultimate objective of sustainable forest management is to meet the forest-related needs and aspirations of the current generation without compromising the ability of future generations to meet their own. To achieve this objective, it is necessary 
to maintain, or even enhance, the forest values important to society or likely to be so in the future. In practice, sustainable development faces some limitations including the present state of technology and social organization on environmental resources and the ability of the biosphere to absorb the effects of human activities. But technology and social organization can be both managed and improved to make way for a new era of economic growth. Both internal a sustainability process that builds local technical capacity and management skills and ensures continuing socio-economic improvement and an environmentally sustainable program of land and natural resource use to ensure long-term viability must be included in the design of any significant effort.

\subsection{Development of participatory forestry in Bangladesh}

There is a growing consensus amongst key forest decision-makers in Bangladesh that traditional forestry needs to make the transition to a more sustainable forestry, which is likely to involve an iterative process of continuous improvement. In this regard, the government has attached the highest priority to participatory forestry program. This program has been launched with the goal of involving local communities in managing forest resources. It has become the dominant strategy in the country's forestry sector (Task Force Reoprt, 1987; GOB, 1992; FMP, 1992; Khan and Begum, 1997). Accordingly, Bangladesh joined the rest of the world in adopting Agenda 21, “a program of action for sustainable development, the Rio Declaration on Environment and Development, and the Statement of Principles for Sustainable Development of Forests, etc.” during the Rio Earth Summit (UNCED) in 1992. 
Participatory forestry activities began in Bangladesh in 1980 with the initiation of a forestry extension program under a Forest Department project with domestic funding. The first formal participatory forestry program was initiated in the north-western districts of Bangladesh in 1981/82 under the Community Forestry Program with the assistance of an Asian Development Bank (ADB) loan and United Nations Development Program (UNDP) grant. After completion of this program in 1987, the Forest Department initiated another ADB assisted program as a part of the Thana Afforestaion and Nursery Development Project in 1988-94 as a follow up of the previous program and operated throughout the Sal forests. Agroforestry and woodlot models have been followed in this project where 1 1.2 ha of encroached Sal forest land was allotted to each participant based on an annually renewable basis. The program proposed to establish 16,188 ha of woodlot and 3,238 ha of agroforestry plantations and a total of 16,840 ha of woodlot and 3,061 ha of agroforestry plantations were raised during the proposed period (Chowdhury, 1994). The specific objectives of the participatory forestry program were: (i) to protect, manage and develop forests in a sustainable way by involving local communities; (ii) to increase forest resources in order to improve the local environment; (iii) to contribute to alleviating rural poverty through involving the local poor and weaker sections of the society in forest management through income-generating activities; and (iv) to strengthen the institutional capacity of the Forest Department. After completion of this program, a Forestry Sector Program for the year 1997-2004 was initiated. The program proposed to establish 20,786 ha of woodlot and 11,905 ha of agroforestry plantations on degraded Sal forests and also on areas where trees from a previous program had already been harvested (second rotation). The objectives of this program were: (i) to increase the overall tree 
resource base of the country; (ii) to arrest the depletion of forest resources, (iii) to enhance the conservation of forests in selected protected areas; and (iv) to attain sustainable management of forest resources through local community participation. All these objectives were targeted as important steps towards extending the capacity of both the state and civil society to manage forests in a sustainable manner (thus conserving their ecological functions), and increasing value-generation from goods and services of forest towards sustainable (rural) development.

\subsection{The research problem and objectives}

Much of the literature on participatory forestry in Bangladesh evaluates mainly the existing conditions and management problems of participatory forestry in Bangladesh (ADB, 2001a; 2001b; Khan and Begum, 1997; Asaduzzaman, 1989; Bhuiyan, 1991; Islam, 2000). Although sustainable development is the prime goal of participatory forestry and sustained participation of farmers is the central component of sustainable participatory forest management, no study has identified the factors influencing farmers’ sustained participation in participatory forestry. Because of a shift in forest management policy from traditional forest management through total exclusion of local people to forest management involving local people on a partnership basis, forest management has become more complex as there are now multiple objectives to attain (Warner, 1997). A gap between what is known by researchers, project personnel and community members and what is utilized by policy-makers, planners and project designers exists that hinders the sustainable development of participatory forestry (Warner, 1997). Participatory forestry is particularly susceptible to a gap in the flow of information because it requires a broader approach that goes beyond the forests and trees and inclusion of participants as 
well as community members. To meet the criteria for sustainable development of participatory forestry, policy-makers, planners and project designers should gather input within the context of dynamic interaction between communities, trees and forests and understanding of the impact of factors such as policy, economics and conflicts on sustainable development. Because sustained participation of farmers in participatory forestry is the cornerstone of sustainable management of participatory forestry, this study aims at determining the factors that may influence farmers to sustained participation in participatory forestry projects.

\section{Materials and methods}

\subsection{Study site}

The plain-land forests in Bangladesh, commonly known as 'Sal forests' can be divided into two parts: Central and Northern. Central Sal forests are located in Dhaka, Gazipur, Tangail, Mymensingh and Jamalpur districts and the northern Sal forests are distributed in small patches in Dinajpur, Rangpur and Rajshahi districts. The Sal forest under the Forest Department consists of 120,255 ha of which 104,616 ha (about 87\%) are located in the central region and the remaining 15,639 ha (about 13\%) are located in the northern region. The study was conducted in the central Sal forests areas in Bangladesh. Sal forests have been dramatically reduced in area and now exist only in a number of widely scattered and degraded patches. The forests consist of patches of Sal (Shorea robusta) coppice occasionally with other tree species. Sal forests areas have maximum encroachment and most of the root stock of remnant Sal forests has lost coppicing power suggesting the use of plantations for re-afforesting such areas. About 20,382 ha of central 
Sal forest lands were distributed among 18,940 participants for the participatory forestry program (Forest Department, 2001).

For many years up to 1950, the Sal forests were under the control of Zaminders (land lords) who were not interested in protecting forests. They emphasized the forests' economic benefits and tried to maximize their revenue at the cost of over exploitation of forest resources. In 1950 the government instituted the East Bengal State Acquisition and Tenancy Act (EBSATA), which abolished the Zamindari system, and forests came under the control of the Forest Department. After gaining control of the Sal forests, the Forest Department adopted many working plans. All the plans failed to protect forests from the hostile actions of the local people. Recognizing their weakness as forest manager, the Forest Department started a participatory forestry program involving local people in these forest areas from 1987.

\subsection{Methods}

The study is based on primary cross-sectional data collected using the multistage stratified random sampling. There are three forest divisions in the central Sal forests: Dhaka, Tangail, and Mymensingh. Each forest division is divided into a number of administrative blocks known as beat. There are 22 beats in Dhaka forest division, 31 beats in Tangail forest division and 22 beats in Mymensingh forest division. At first, four beats one from each forest division were selected randomly. From each selected beat 150 households of farmers were selected randomly, yielding 600 households in total. At the time of survey, 19 selected participants migrated temporarily from the study areas and did 
not return during the survey period; they were therefore discarded from the study. Thus, the sample consisted of 581 households of farmers. The research used interview and field observation methods. The sample unit was the household of the selected farmer who is the respondent. Interviews were conducted during August-November 2001 by a research team using a pre-tested questionnaire. The language used during the survey was Bengali. Data were analyzed by SPSS package program.

\subsection{Statistical analysis}

To identify factors that may influence the sustained participation of farmers in participatory forestry program, a discrete variable logit analysis was carried out. The opinion of the participants as to whether they were interested in sustained participation in participatory forestry can be framed as binary-choice models which assume that individuals are faced with a choice between two alternatives (participation/not participation) and the choice depends on identifiable characteristics. Let $T_{i}$ represents a dichotomous variable that equals 1 if the respondent is in favor of sustained participation in participatory forestry and 0 otherwise. The probability of farmers' sustained participation in participatory forestry, $\operatorname{Pr}\left(\mathrm{T}_{\mathrm{i}}=1\right)$, is a cumulative density function $\mathrm{F}$ evaluated at $X_{i} \beta$, where $\mathrm{X}_{\mathrm{i}}$ is a vector of explanatory variables and $\beta$ is a vector of unknown parameters. This kind of cumulative density function can be modeled using logistic probability function, which has the following form:

$$
P_{r}(\text { Farmers' sustained participation })=P_{r}\left(T_{i}=1\right)=\frac{\exp \left(X_{i} \beta\right)}{1+\exp \left(X_{i} \beta\right)} \text {. }
$$


The estimation form of logistic transformation of the probability of participants' opinions in favor of sustained participation $P_{r}\left(T_{i}=1\right)$ can be represented as:

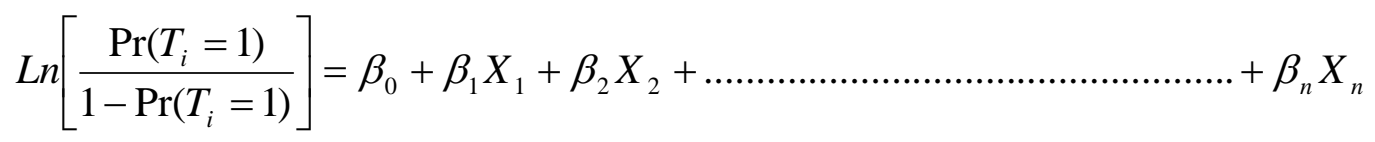

In order to estimate the parameters of the variables influencing participants to be in favor of sustained participation in participatory forestry, a maximum likelihood estimation was used as shown in equation (1).

\subsubsection{Variables used in the model}

The Outcome variable: The outcome variable is sustained participation of farmers in participatory forestry, which is coded with the value 1 to indicate the farmer's opinion in favor of sustained participation and zero otherwise.

Independent variables: It is assumed that the factors listed in Table 1 may influence farmers toward sustained participation in participatory forestry and thus the factors were included in the model as independent variables. Characteristics of the independent variables are shown in Table 1.

\subsubsection{Model}

Given the above hypothesized factors of farmers' attitudes in favor of sustained participation, the model to be estimated is: 


$$
\begin{aligned}
\operatorname{Ln}\left[\frac{\operatorname{Pr}\left(T_{i}=1\right)}{1-\operatorname{Pr}\left(T_{i}\right)}\right]= & b_{0}+b_{1}(S P)+b_{2}(F D S A)+b_{3}(S S P)+b_{4}(A B S S)+b_{5}(F B R H) \\
& +b_{6}(P F D L)+b_{7}(L P A P)+b_{8}(C F D)+b_{9}(A P C)+b_{10}(R F B) \\
& +b_{11}(F D P T)+b_{12}(R A F D)+b_{13}(G T G F)
\end{aligned}
$$

where

SP $=$ a dummy variable indicating whether the farmer (respondent) is satisfied in participating in participatory forestry or not;

FDSA $=$ a dummy variable indicating whether the Forest Department officials seek advice/opinion from the farmers or not;

SSP $=$ a dummy variable indicating whether the farmer is satisfied with the species planted or not;

ABSS $=$ a dummy variable indicating whether the farmer agrees with benefit sharing system or not;

$\mathrm{EBRH}=$ a dummy variable indicating whether the farmer think that he would receive aspired benefits after final harvesting of trees or not;

PFDL = a dummy variable indicating whether participatory forestry disrupted interests of any local people or not;

LPAP = a dummy variable indicating whether local people accepted participatory forestry gladly or not;

CFD = a dummy variable indicating whether the farmer had conflicts with the Forest Department officials or not;

APC $=$ a dummy variable indicating whether contractual agreement period of farmer's plot was completed or not; 


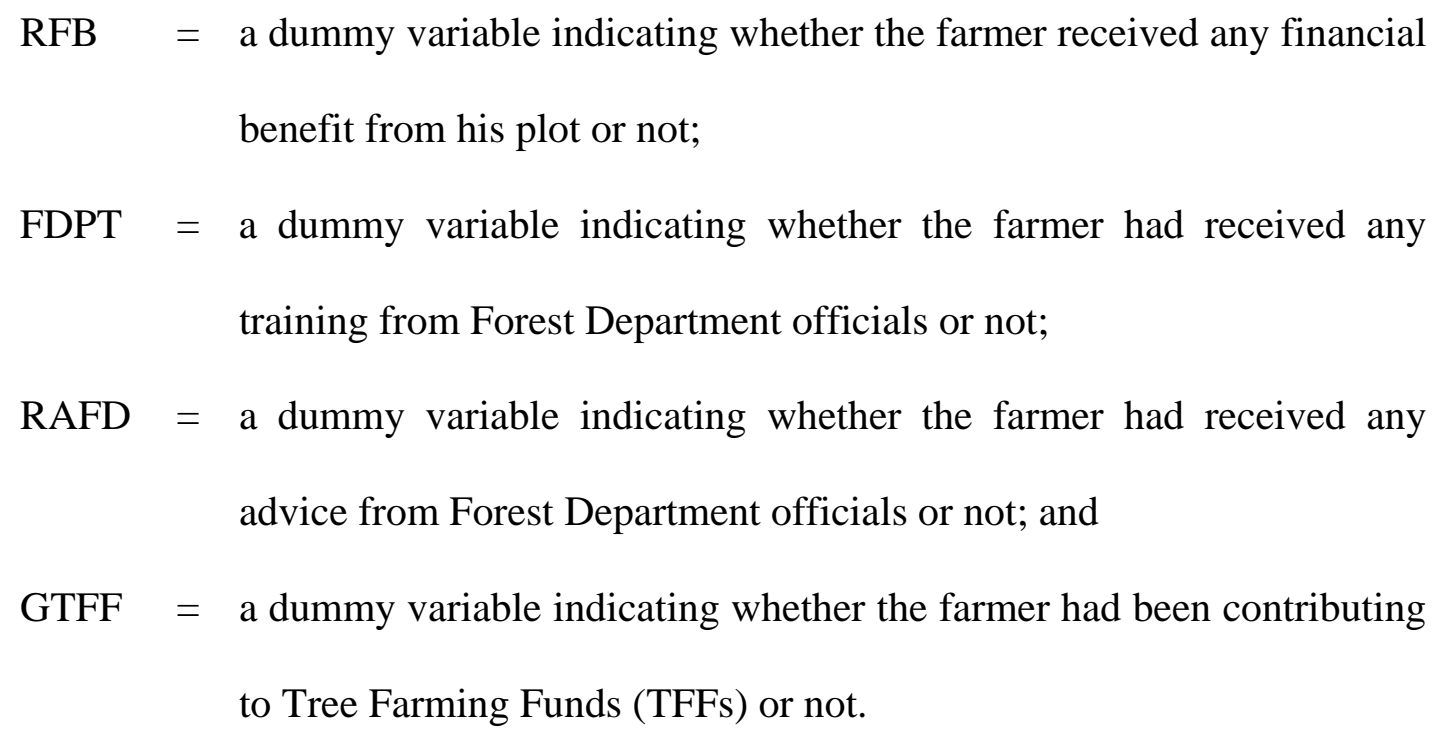

\subsubsection{Tests of hypotheses of the logistic regression model}

Because of the large sample size, the test that a coefficient is 0 can be based on the Wald statistic, which has a $\chi^{2}$ distribution. When the variable has a single degrees of freedom, the Wald statistics is just the square of the ratio of the coefficient to its standard error. The corresponding $\chi^{2}$ critical values at the $1 \%$ and at the $5 \%$ level of significance will determine a rejection or an acceptance of the null hypothesis.

The null hypothesis in the model, $H_{0}: \beta_{r}=0$, where $r=1,2, \ldots \ldots \ldots \ldots, 13$, is rejected. This result indicates that the variables in the logistic regression model have significant influence on farmers' sustained participation. 


\section{Results}

\subsection{Characteristics of the variables included in the model}

Table 1 shows the percentage distribution of farmers according to the variables included in the logistic regression model. It is evident from the table that about $60 \%$ of the participants were in favor of sustained participation in participatory forestry. About $76 \%$ of participants were satisfied with having involved in the participatory forestry program. About $64 \%$ of participants were satisfied with the species planted. About $96 \%$ of participants were in agreement with the benefit sharing system. About $76 \%$ of participants believed that they would receive benefits after the final felling. About $82 \%$ of participants opined that local people accepted participatory forestry enthusiastically. About 54\% of participants had received financial benefits from their participatory forest plots. About 56\% of participants mentioned that the Forest Department provided training to participants on participatory forestry activities. About $60 \%$ of respondents received advice on participatory forestry from Forest Department officials. About $10 \%$ of participants contributed money to Tree Farming Funds (TFFs) either to a local participants’ society or to the Forest Department’s TFFs.

\subsection{Parameter estimates of the logistic regression model}

Table 2 shows the logistic regression model with 13 independent variables. The results of the logistic regression analysis suggest that participants' satisfaction with the planted species (SSP) is significantly different from zero at 5\% significance level of $\chi^{2}$ value with expected positive sign. The odds-ratio indicates that participants who were satisfied with the planted species are 1.6 times more likely to show their interests in sustained 
participation in participatory forestry projects than those who were dissatisfied with the planted species. Concurrence of participants with the benefit sharing principle (ABSS) is significantly different from zero at $1 \% \chi^{2}$ value with an unexpected negative sign. Participants' confidence on getting exact benefits after the final felling of trees $(\boldsymbol{F B R H})$ is significantly different from zero at $1 \% \chi^{2}$ value with an expected positive sign. The odds-ratio indicates that participants who were assured of receiving their share of benefits after final harvesting were 3.8 times more likely to show their interest in sustained participation than those who were not assured their benefits. Disruption of local people's interests through implementation of participatory forestry (PFDL) is significantly different from zero at the $1 \%$ significant level of $\chi^{2}$ value with an expected positive sign. The delay in harvesting trees after completion of the agreement period (APC) is significantly different from zero at the $1 \% \chi^{2}$ value with an expected negative sign, demonstrating that the felling of trees just after completion of the agreement period influenced farmers in sustained participation. Training of participants on participatory forestry activities (FDPT) is significantly different from zero at the $1 \% \chi^{2}$ value with an expected positive sign. Odds-ratio shows that participants who had received training on participatory forestry are 2.4 times more likely to show an interest in sustained participation than those who did not receive any training. The Forest Department's advice to participating farmers regarding participatory forestry activities (RAFD) is significantly different from zero at the $1 \%$ significance level and has an unexpected negative sign. The generation of a Tree Farming Fund (GTFF), either locally or under the supervision of Forest Department, is significantly different from zero at the $1 \%$ level of significance of $\chi^{2}$ value with has an expected positive sign. The value of odds-ratio indicates that 
participants who contributed money to TFFs were 7.7 times more likely to show an interest in sustained participation than those participants who did not contribute money to TFFs.

\section{Discussion}

Sustainable development of participatory forestry requires an appreciation, effective support and active participation of farmers. Thus, efforts should be taken to consider farmers' needs and aspirations. This includes: (i) recognizing and seeking local knowledge, skills and experiences for developing participatory forestry; (ii) understanding the interests and motives of participants; (iii) helping to identify and strengthen local institutional capacities; and (iv) challenging and revising inaccurate assumptions about the nature and causes of local environmental problems. Farmers' appreciation and effective support can be enhanced by the meaningful participation of farmers during policy, program, project, and activity design in order to determine the priorities, objectives and activities of participatory forestry (Warner, 1997). The chance for success in sustainable participatory forest development would seem to be through processes that recognize and involve the multiplicity of ideologies, interests, objectives and knowledge of the individuals that have a stake in the matter. And that is why the legitimate roles of different stakeholders in sustainable forest development was explicitly recognized at the United Nations Conference on Environment and Development held in RIO de Janerio in 1992, and in many subsequent national and international gatherings. Where forests continue to be central to livelihood systems, local people should be the main stakeholders and meeting their needs and aspiration on a sustainable basis is the key 
factor for sustainable development of participatory forestry (Peluso and Padoch, 1996). Unless such factors are considered in forest management strategy, there is little incentive for people to involve themselves effectively in sustainable forest management. However, few developing countries broadly recognize participants' contributions to decisionmaking in sustainable forest management (Thrupp et al. 1997). The information derived from this study supports the above notion clearly. About three-fifth of participants showed an interest in sustained participation in the participatory forestry program. Statistical analyses and tests of hypotheses identified some significant factors that might influence farmers toward sustained participation.

About 36 percent of the participants were not satisfied with the species of trees planted in their plots and logistic regression analysis indicates that satisfaction of participants with planted species (SSP) is a significant factor for farmers' sustained participation in participatory forestry program. This factor for farmers' sustained participation can be effectively met by involving local people in the decision-making process at the initial stages of the program. But the decision-making process in Bangladesh for participatory forestry is still "top—down” where upper level decision makers of the Forest Department initiate managerial and technical decisions and the Forest Department execute those decisions at the field levels after approval of the Ministry of Environment and Forest. Participants have no scope to participate in any stage of decision-making process under the present system. Even field level Forest Department officials have no effective scope to incorporate their field experiences into the forest management strategy. Attempts to manage participatory forests on a long-term basis without accommodating multiple 
interests in decision-making and implementation process have generally failed. In India and Nepal, National and State Forest Departments are turning to more process-oriented, less target-based planning, aimed at shifting control and management of forest lands from the Forest Department to decentralized people's organization (Hobley, 1996; Malla, 1997; HMGN, 1989; Gilmour and Fisher, 1991; Metz, 1991; Kumar and Bakshi, 2002). And thus community forestry in these countries has contributed greatly to the development of forest resource management institutions at the grassroots level (Sarin, 1995; Singh et al. 1997; Malla, 2000; Jain and Singh, 2000; Paudel and Thapa, 2002).

Participatory forest management seeks to develop effective partnerships between partners for sustainable management and joint benefit sharing of public forest landuse. The longterm sustainability and replication of participatory forestry depend on higher and assured personal economic returns (Jain and Singh, 2000). One of the most important reasons for rapid expansion of the Joint Forest Management system in West Bengal of India is the assured promise of share of income from final harvesting (Sarin, 1995). The suspicions of participants about their share of benefits may disrupt farmers' sustained participation. In the case of participatory forestry in Bangladesh, about one fourth of the participants were suspicious about their share of benefits from the final harvesting of trees. Regression analysis supports significantly the hypothesis that participants' confidence about getting their share of benefits from final harvesting of trees $(\boldsymbol{F B R H})$ is positively related with the sustained participation of farmers in participatory forestry program. 
Recent research indicates that a forest management strategy has more potential to attain sustainable forest management where the Forest Department introduces forest management jointly with the local people, building on the mutual benefits to be obtained from greater access to forest products by local people and reduced protection costs for the Forest Department (Gow, 1992). One way to develop forest management of this type is through the consideration of social, economic and political factors that may affect or be affected by the local people because of implementation of the project. In realizing the considerable potential of participatory forestry to benefit a local community, one of the principal challenges the Forest Department, managers and scientists face is to progress from a narrow focus, which Shiva (1993) has characterized as "monocultures of the mind" to a broader appreciation of forestry purpose and practices. To establish mutually enforceable, appropriate, secure and enduring relationships with local people that promote sustainable participatory forest management, its policy must support the valid priorities and claims of local people in implementing forestry related activities (Bruce and Migot-Adholla, 1994; Seymour and Rutherford, 1993; Hunt et al. 1996; Jackson and Ingles, 1995). Participatory forestry should begin with participatory appraisal activities, followed by a series of negotiation and planning meetings to reach a basic consensus (Ramfrez, 1998). Agreed language is essential to bridge differences and find a 'common mental map' (Bernard and Armstrong, 1997; cited in Ramfrez, 1998). The results of regression analysis significantly support the hypothesis that disagreement of local people with the existing benefit-sharing system (ABSS) has negative impact on sustained participation of farmers. The disruption of local people from their interests may also divert the farmers from 'common mental map' and thus may hinder sustained 
participation of community members in the program. The results of regression analysis significantly support this hypothesis demonstrating that disruption of interests of local people at the time of implementation of participatory forestry programs in their locality (PFDL) has a significant negative impact on sustained participation of farmers in participatory forestry.

The Forest Department and the local participants share products, responsibilities and control over forest management in participatory forestry programs. Contractual agreements specify the distribution of authority, responsibilities, agreement tenure, and share of benefits. Participants may be disheartened if any of the contractual agreement conditions would be violated because of the negligence of Forest Department officials. Particularly, they would be worried about their share in benefits if trees of their plots would not be harvested even long after completion of the contractual agreement period. Initial success may be added to the enthusiasm and expectations of the farmers, but later failures to deliver services according to contractual agreement may threaten the farmers' interests in sustained participation. In the study areas, the contractual agreement tenure on about 36 percent of the plots were completed much before the time of survey but the trees on those plots were yet to harvest. Thus, farmers were uncertain about their share of benefits because of the delay in harvesting mature trees. In some areas of Tangail and Mymensingh forest divisions, illegal loggers in collaboration with some dishonest forest officials, local elites and participants logged all the mature trees of some plots where trees of those plots had not been harvested long after completion of agreement period. The results of regression analysis also significantly support the hypothesis that 
participants may be indifferent to sustained participation if trees of their plots were not harvested within a short period of time after completion of the contractual agreement period (APC).

Local participants often lack appropriate technologies and broader perspectives on management techniques of participatory forestry through which they can provide input to their maximum potential to sustainable forest development. Thus participants should be trained on different aspects of participatory forestry so that they can compete successfully for new jobs associated with the transition to ecosystem management. A training manual should be built on the field experiences of field level Forest Department officials and the local knowledge that many local people already possessed. This type of training would not only develop local capacities for sustainable forest management but also would change inefficient government policies and practices. Because of enhancing and updating their skills and knowledge on participatory forestry, farmers would be encouraged to involve themselves in sustained participation. The results of regression analysis significantly support the above hypothesis indicating that training of participants on different aspects of participatory forestry (FDPT) is positively related with farmers' sustained participation.

Sustainable development of participatory forestry means increasing the potential of local people to influence and control their future on a long-term basis, a goal that can be achieved by strengthening their rights, capacity, and fostering empowerment (Gow, 1988). The continued stimulation of this demand for capacity building and development 
of methodologies to satisfy this demand would be the bottom line of sustained involvement of farmers within participatory forestry programs. The key is to ensure that local people see themselves as contributors to forest development and hence some ownership of their plots. In this process, a resourceful initiative to establish TFFs at the grassroots level was proposed in the Forestry Sector Project of Bangladesh in 1997. In the TFFs, $10 \%$ of the revenues from final harvesting of the existing plots would be deposited to TFFs to undertake more such participatory forestry programs. Participants who would like to participate in sustainable forestry would appreciate the initiative and would gladly contribute money to TFFs. In some study areas, participants were also generating local funds by their own initiatives for developing forests when outside funds would be withdrawn from their areas. It is assumed that participants would establish some rights by involving themselves in the process of TFFs. Statistical analysis supports the above hypothesis significantly demonstrating that contribution of participants in TFFs (GTFF) is positively related with their sustained participation in participatory forestry.

\section{Conclusions}

In conclusion, participatory forestry in Bangladesh can be an effective strategy for sustainable development. For the strategy to succeed, participants must be real partners of the Forest Department in forest management. For a successful partnership, participants must have security of long-term rights to the forest so that they are assured that they will receive benefits from the protection and improvement of the forest resources. The link between assured benefits and sustainable development appears to be strong one. As poverty alleviation and sustainable rural development is the most important objective of 
participatory forestry, participants' knowledge, skills, claims and aspirations should be recognized in the strategy of forest management. In this regard, participants should be able to participate actively in decision-making and local institutions must be strengthened. Farmers' sustained participation should be ensured by considering the important lessons

from this study. The lessons drawn from this study are important indicators for appreciating the complexity and dynamics of participatory forestry.

\section{Acknowledgement}

This research was supported by the Japan Society for the Promotion of Science (JSPS) Postdoctoral Fellowship for Foreign Researchers Program, awarded to the first author. The comments of two reviewers greatly improved this paper. 


\section{References}

ADB (2001a). Project performance audit report on the Upazila Afforesstation and Nursery Development Project (Loan 956-BAN[SF]) in Bangladesh. Asian Development Bank.

ADB (2001b). Regional study on forest policy and institutional reforms. Report presented at final consultative workshop, Bangladesh Country Case Study, RETA 5900: Regional Study on Forest Policy and Institutional Reforms, Asian Development Bank, Dhaka, Bangladesh.

Asaduzzaman, M. (1989). Social forestry in Bangladesh. Research Report No. 115, Bangladesh Institute of development Studies, Dhaka, Bangladesh.

Bernard, A.K. and Armstrong, G. (1997). Learning and integration. Prepared for IDRC (Unpublished).

Bhuiyan, A.K. (1991) Program and progress of social forestry in Bangladesh. In: Proceedings of National Workshop on Social and Community Development, October 5-10, Forest, Trees and People Program (FTPP) and FAO, USA.

Bruce, J.W. and Migot-Adholla, S.E. (eds.) (1994). Searching for land tenure security in Africa. Dubuque, Iowa, USA. Kendall/Hunt Publishing.

Chowdhury, R. A. (1994). History and importance of Sal forests and current management status. In: Proceedings of the national workshop on Agroforestry for the Degraded Sal Forests, organized by NAWG and BARC, Dhaka, Bangladesh.

Ferguson, I. S. (1996). Sustainable forest management. Melbourne: Oxford University Press. 
FMP (1992) Bangladesh participatory forestry. Forestry Master Plan, ADB TA 1355BAN UNDP/FAO BGD/088/025.

Forest Department (2001). Manual of training course of forest guards, NGOs field workers, participants, and local elites. Local Training Program, Forestry Sector Project (1997/98 - 2003/04), Forest Department, Government of the People’s Republic of Bangladesh.

Gilmour, D.A. and Fisher, R.J. (1991). Villages, forests and foresters: the philosophy, process and practice of community forestry in Nepal. Sahayogi Press, Katmandu.

GOB (Government of Bangladesh) (1992) A new pledge for a greener Bangladesh. Ministry of Information, Government of the People’s Republic of Bangladesh.

Gow, D.D. (1992). Forestry for sustainable development: The social dimension. Unasylva, 43(2).

Gow, D.D. (1988). Development anthropology: in quest of a practical vision. Development Anthropology Network, 6(2): 13-17.

HMGN (1989). Master Plan for the Forestry Sector. Ministry of Forest and Soil Conservation, Katmandu, Nepal.

Hobley, M. (1996). Participatory forestry: the process of change in India and Nepal. Rural Development Forestry Study Guide No. 3. Rural Development Forestry Network, London, ODI.

Hunt, S.M., Jackson, W.J., and Sheresthra, K.B. (1996). Income generation through community forestry in Nepal. In: M. Victor (ed.) Income generation through community forestry. Proceedings of an International Seminar, Bangkok, Thailand, 18-20 October 1995. RECOFTC, Bangkok. 
Isalm, M.S. (2000) Participatory assessment of agroforestry in the sal forests of two villages, Mymensingh Forest Division, Bangladesh. Swedish University of Agricultural Sciences, Department of Rural Development Studies, MADRAT Program, Sweden.

Jackson, W.J. and Ingles, A.W. (1995). Developing rural communities and conserving the biodiversity of Nepal's forests through community forestry. In: H. Wood, M. McDaniel and K. Warner (eds.) Community development and conservation of forest biodiversity through community forestry. Proceedings of an International Seminar, Bankok, Thailand, 26-28 October 1994. RECOFTC, Bangkok.

Jain, S.K. and Singh, P. (2000). Economic analysis of industrial agrofoerstry: poplar (Populus deltoids) in Uttar Pradesh (India). Agroforestry Systems, 49: 255-273.

Khan, N.A. and Begum, S.A. (1997). Participation in social forestry re-examined: a case study from Bangladesh. Development in Practice, 7(3).

Kumar, N. and Bakshi, S. (2002). Making and breaking a community forestry institution: a case study. Forests, Trees and Livelihoods, 12(3): 165-174.

Malla, Y.B. (2000). Impact of community forestry policy on rural livelihoods and food security in Nepal. Unasylva, 51(3).

Malla, Y.B. (1997). Sustainable use of communal forests in Nepal. Journal of World Forest Resource Management, 8: 51-74.

Metz, J.J. (1991). Community forestry at the Institute of Forestry, Nepal. IOF Project Technical Paper No 91/1, Institute of Forestry, Pokhara.

Paudel, G.S. and Thapa, G.B. (2002). Local forest and rangeland management system in the hills of Nepal. Banko Janakari, 12(1): 54-61. 
Peluso, N.L. and Padoch, C. (1996). Changing resource rights in managed forests of West Kalimantan. In C. Padoch and N.L. Peluso, eds. Bomeo in transition: people, forests, conservation and development. Singapore, Oxford University Press.

Ramfrez, R. (1998). Participatory learning and communication approaches for managing pluralism. Unsylva, 49(3).

Sarin, M. (1995). Joins forest management in India: achievements and unaddressed challenges. Unasylva, 46(1).

Seymour, F.J. and Rutherford, D. (1993). Contractual agreements in the Java Social Forestry Program. In: Legal Frameworks for Forestry Management in Asia: Case Studies of Community/State Relations. Honolulu, Hawaii, USA, East-West Center Program on Environment.

Shiva, V. (1993). Monocultures of the mind. Zed Books. 184 p.

Singh, G., Singh, N.T., Dagar, J.C., Singh, H. and Sharma, V.P. (1997). An evaluation of agriculture, forestry and agrofoerstry practices in a moderately alkali soil in northwestern India. Agroforestry Systems, 37: 279-295.

Task Force Report (1987). Participatory forestry in Bangladesh: Concepts, experiences and recommendations. Ministry of Agriculture, Government of the People's Republic of Bangladesh.

Thrupp, L.A., Hecht, S.B. and Brower, J.O. (1997). The diversity and dynamics of shifting cultivation: myths, realities, and policy implications. Washington, DC, World Resources Institute. 
Warner, K. (1997). The vision and role of community forestry in sustainable development. In: Proceedings of the XI World Forestry Congress, Antalya, Turkey, 13-22 October, 1997. 
Table 1: Percentage distribution of farmers according to variables included in model 1.

\begin{tabular}{lll}
\hline Variable & Yes & No
\end{tabular}

Dependent Variable

Farmers’ attitudes in favor of sustained participation $\quad 60.4 \quad 39.6$

\section{Independent variable}

$\begin{array}{lll}\text { Whether satisfied for participation in the participatory } & 76.4 & 23.6\end{array}$

forestry (SP)

Whether forest department officials seek advice/opinion from

the farmers (FDSA)

Whether satisfied with the species planted (SSP)

$63.8 \quad 36.2$

Whether agree with benefit sharing system (ABSS)

$96.0 \quad 4.0$

Whether think that aspired benefits would be received after

76.4

harvesting trees (FBRH)

Whether participatory forestry practice disrupted interests of $\quad 16.5$

the local people (PFDL)

Whether local people accepted participatory forestry gladly $\quad 81.6$

(LPAP)

Whether there was any conflicts with the Forest Department

2.1

97.9

officials (CFD)

Whether agreement period was completed (APC)

35.5

64.5

Whether received any financial benefit from the forests

54

46

(RFB)

Whether the Forest Department provide training to the

56.4

43.6

participants (FDPT)

Whether received any advice from the Forest Department

59.8

40.2

officials (RAFD)

Whether contributing to TFFs (GTFF)

10.0

90.0 
Table 2: Logistic Regression Analysis

Dependent Variable: Whether farmers' attitude in favor of sustained participation

\begin{tabular}{|c|c|c|c|}
\hline Independent variable & Coefficient & $\begin{array}{l}\text { tandard } \\
\text { error }\end{array}$ & $\begin{array}{l}\text { Odds- } \\
\text { ratio }\end{array}$ \\
\hline $\begin{array}{l}\text { Whether satisfied for participation in the participatory } \\
\text { forestry (SP) }\end{array}$ & .007 & .035 & 1.007 \\
\hline $\begin{array}{l}\text { Whether Forest Department officials seek } \\
\text { advice/opinion from the farmers (FDSA) }\end{array}$ & .367 & .476 & 1.44 \\
\hline Whether satisfied with the species planted (SSP) & $.461^{*}$ & .203 & 1.586 \\
\hline Whether agree with benefit sharing system (ABSS) & $-2.264 * *$ & .575 & .104 \\
\hline $\begin{array}{l}\text { Whether think that exact benefit would be received after } \\
\text { harvesting trees (FBRH) }\end{array}$ & $1.343^{* *}$ & .273 & 3.829 \\
\hline $\begin{array}{l}\text { Whether participatory forestry practice deprived } \\
\text { anybody local people (PFDL) }\end{array}$ & $-.852 * *$ & .295 & .427 \\
\hline $\begin{array}{l}\text { Whether local people accepted participatory forestry } \\
\text { gladly (LPAP) }\end{array}$ & .099 & .090 & 1.104 \\
\hline $\begin{array}{l}\text { Whether there was conflict with the Forest Department } \\
\text { officials (CFD) }\end{array}$ & .789 & .756 & 2.201 \\
\hline Whether agreement period was completed (APC) & $-.733 * *$ & .228 & .480 \\
\hline $\begin{array}{l}\text { Whether received any financial benefit from the forests } \\
(\boldsymbol{R F B})\end{array}$ & .121 & .217 & 1.129 \\
\hline $\begin{array}{l}\text { Whether the Forest Department provide training to the } \\
\text { participants (FDPT) }\end{array}$ & $.879 * *$ & .220 & 2.408 \\
\hline Whether received any advice from the Forest & $-.666 * *$ & .217 & .514 \\
\hline Department officials (RAFD) & & & \\
\hline Whether generating TFFs (GTFF) & $2.046^{* * *}$ & .483 & 7.738 \\
\hline Constant & $-4.512 *$ & & \\
\hline Model $\chi^{2}$ & $147.37 *$ & & \\
\hline
\end{tabular}

Note: $*^{*}{ }_{---p}<.01 ;$ and ${ }^{*}--\mathrm{p}<.05$ 